\title{
Meningkatkan Hasil Belajar Mata Kuliah Bahasa Indonesia melalui Model Pembelajaran Project Based Learning
}

\author{
Tekad Budiantoro ${ }^{1)}$ \\ Politeknik Negeri Tanah Laut \\ Email Penulis: tekad@politala.ac.id
}

\begin{abstract}
Abstrak
Kegiatan perkuliahan Bahasa Indonesia dituntut agar mampu menggunakan bahasa sebagai sarana komunikasi, menggunakan bahasa Indonesia secara baik dan benar sesuai dengan situasi dan keperluan. Tujuan dari penelitian ini adalah untuk mendeskripsikan peningkatan hasil belajar mahasiswa pada mata kuliah Bahasa Indonesia setelah menerapkan model project based learning. Penelitian ini adalah Action Research dengan dua siklus. Hasil penelitian menunjukkan adanya peningkatan kualitas hasil perkuliahan yang ditunjukkan dengan adanya perubahan rata-rata skor nilai dari siklus satu ke siklus berikutnya. Jumlah subyek penelitian adalah 34 orang mahasiswa. Data dikumpulkan dengan menggunakan tes hasil belajar pada setiap siklus. Data dianalisis secara deskriptif kuantitatif. Hasil penelitian menunjukkan bahwa rata-rata persentase meningkat dari $83 \%$ menjadi $96 \%$. Dengan demikian, dapat disimpulkan bahwa model project based learning dapat meningkatkan hasil belajar mahasiswa pada mata kuliah Bahasa Indonesia.
\end{abstract}

Kata Kunci: Mata kuliah Bahasa Indonesia, project based learning, kemampuan berbahasa

\begin{abstract}
Bahasa Indonesia lecture activities are demanded to be able to use language as a means of communication, to use Indonesian properly and correctly in accordance with situations and needs. The purpose of this study is to describe the improvement of student learning outcomes in Indonesian language courses after applying the project based learning model. This research is Action Research with two cycles. The results showed an increase in the quality of the results of lectures as indicated by the change in the average score from one cycle to the next cycle. The number of research subjects was 34 students. Data were collected using a test of learning outcomes in each cycle. Data were analyzed descriptively quantitatively. The results showed that the average percentage increased from $83 \%$ to $96 \%$. Thus, it can be concluded that the project based learning model can improve student learning outcomes in Indonesian language courses.
\end{abstract}

Keywords: Bahasa Indonesia Lecture, Project Based Learning, Language Skill

\section{PENDAHULUAN}

Penyelenggaraan perkuliahan mata kuliah Bahasa Indonesia pada Politeknik Negeri Tanah Laut, mengacu pada Surat Keputusan Direktur Jenderal Pendidikan Tinggi Departemen Pendidikan Nsional Republik Indonesia Nomor 43/DIKTI/Kep/2006 Tanggal 6 September 2006 yang menyatakan bahwa mata kuliah Bahasa Indonesia merupakan salah satu dari kelompok Mata Kuliah Pengembangan Kepribadian (MPK) atau Mata Kuliah Dasar Umum (MKDU) pada perguruan tinggi Indonesia. Sebagai salah satu mata kuliah pengembangan kepribadian, perkuliahan Bahasa Indonesia lebih menitikberatkan pada pembinaan keterampilan mahasiswa dalam menggunakan Bahasa Indonesia secara baik dan benar dalam berkomunikasi. Keterampilan tersebut dimanfaatkan antara lain untuk 1) menuangkan ide, pikiran, gagasan, dan sikap ilmiah ke dalam berbagai bentuk karya tulis ilmiah sederhana yang baik dan berkualitas, dengan memperhatikan syarat obyektivitas, efektivitas, kohesi, koherensi, efisien dan komunikatif; 2) menyunting secara cerdas dan kritis berbagai sumber tertulis, dan memanfaatkannya untuk berbagai keperluan secara benar; 3) memanfaatkan keterampilannya dalam berbahasa Indonesia baik secara lisan maupun tertulis untuk berkomunikasi dan pengembangan kepribadiannya secara utuh. Berbagai keterampilan berbahasa mahasiswa tersebut dibina melalui empat aspek dasar kebahasaan yaitu kegiatan menyimak, kegiatan berbicara, kegiatan membaca, dan 
kegiatan menulis. Oleh karena itu, kuliah bahasa Indonesia dituntut untuk mampu membina dan mengembangkan aspek-aspek tersebut secara maksimal dan seimbang. Disinilah peran, kreativitas dan inovasi dosen pengajar mata kuliah Bahasa Indonesia sangat dibutuhkan.

Berbagai cara pendekatan, strategi, metode dan teknik pembelajaran perlu dicoba dan dikembangkan guna memperoleh hasil yang optimal sebagaimana yang diharapkan.Keberhasilan proses pembelajaran dipengaruhi oleh sejumlah faktor yang komponen manajemen proses pembelajaran termasuk penggunaan berbagai macam model pembelajaran inovatif (Ismuwardani, Nuryatin, \& Doyin, 2019). Salah satu model pembelajaran yang dapat digunakan adalah project based learning. Project Based Learning merupakan sebuah model pembelajaran yang sudah banyak dikembangkan di negara-negara maju seperti Amerika Serikat (Niswara, Muhajir, \& Untari, 2019). Model Project based learning direkomendasikan untuk implementasikan dalam pembelajaran (Dewantara, 2015; Ismuwardani et al., 2019).

Project based learning diharapkan mampu membangun iklim belajar yang positif dan mendorong partisipasi mahasiswa secara aktif. Seluruh potensi kebahasaan yang dimiliki mahasiswa hendaknya terbina secara simultan dan maksimal, baik dalam hal kemampuan menyimak, keamampuan berbicara atau berkomunikasi lisan, kemampuannya dalam hal membaca, terlebih-lebih kemampuannya dalam tulis-menulis. Penelitian sebelumnya telah menyatakan bahwa Project Based Learning dapat meningkatkan hasil belajar (Dewantara, 2015; Irmawati, Khoirunnisya, \& Syarifah, 2019).

Berdasarkan latar belakang tersebut, peneliti melakukan suatu action research untuk meningkatkan hasil belajar dengan menggunakan model project based learning. Rumusan masalah dari penelitian ini adalah bagaimana peningkatan hasil belajar mahasiswa pada mata kuliah Bahasa Indonesia setelah menerapkan model project based learning. Dengan demikian, tujuan dari penelitian ini adalah mendeskripsikan peningkatan hasil belajar mahasiswa pada mata kuliah Bahasa Indonesia setelah menerapkan model project based learning.

\section{Model Pembelajaran Project Based Learning (PBL)}

Project based learning adalah suatu pembelajaran yang berpusat pada peserta didik sehingga dapat membuat peserta didik mandiri (Lao, 2019). Project Based Learning memberikan peluang kepada siswa untuk belajar secara lebih maksimal dengan memanfaatkan potensi yang ada di dalam dirinya (Teguh, Suyanto, \& Munaris, 2019). Project-Based Learning berisi 6 fase utama yang dimulai dengan orientasi masalah yang disampaikan guru untuk mengarahkan siswa tentang situasi masalah dan membentuk kelompok, melakukan investigasi, merencanakan laporan, presentasi laporan, dan evaluasi (Suantara, Darmawiguna, \& Sugihartini, 2019).

Materi pengajaran mata kuliah Bahasa Indonesia dalam model pembelajaran Project Based Learning ini tidak dipelajari satu persatu secara terpisah tetapi dikaji dan dipelajari secara simultan dalam satu kesatuan. Mempelajari satu kompetensi sekaligus dapat mempelajari kompetensikompetensi yang lain. Materi-materi kebahasaan seperti penggunaan ejaan, diksi, pengembangan dan pola kalimat, serta pengembangan paragraf dapat dipelajari dalam satu kegiatan atau project, yaitu penulisan karya ilmiah. Dengan kegiatan menulis karya ilmiah, maka mahasiswa belajar secara langsung dan simultan tentang aturan bahasa tulis, bagaimana menulis kata dan ejaan secara benar, mengembangkan kalimat secara benar, serta membangun paragraf lengkap secara benar. Pada langkah akhir dari project ini mahasiswa mempresentasikan karya tulisnya kepada mahasiswa lain di depan kelas. Langkah ini penting bagi mahasiswa, sebagai wahana latihan pengembangan keterampilan berbicara di depan umum. Kegiatan perkuliahan dengan model Project Based Learning ini tidak sebatas penjelasan teori dan penyampaian informasi-informasi pengetahuan, tetapi berupa penerapan dan praktek atas teori-teori tersebut dalam satu bentuk kegiatan project. Dari hasil project itu pulalah kompetensi mahasiswa akan dapat diukur dan dinilai. Demikian demikian, pelaksanaan evaluasi pengukuran dan penilaian atas kompetensi kebahasaan mahasiswa tidak dilakukan secara terpisahpisah, tetapi dapat dilakukan dalam satu format penilaian portofolio, atas hasil pekerjaan mahasiswa.

Pengembangan model Project Based Learning (PBL) pada kuliah Bahasa Indonesia ini sesungguhnya terdorong oleh keinginan untuk menghadirkan sebuah variasi strategi perkuliahan, yang dapat meningkatkan semangat dan motivasi mahasiswa, mencegah kejenuhan akibat metode perkuliahan yang monoton, serta memberi kesempatan kepada mahasiswa untuk aktif berekspresi dalam belajar. Selain itu, PBL memberi banyak keuntungan di luar variabel yang diselidiki dalam 
penelitian ini, misalnya: 1) kesiapan siswa untuk menerima saran dari teman-teman mereka, 2) evaluasi diri, 3) menyelesaikan masalah mereka(Jaya, Hermansyah, \& Rosmiyati, 2019).

\section{Pembelajaran Bahasa Indonesia di Perguruan Tinggi}

Berdasarkan Surat Keputusan Direktur Jenderal Pendidikan Tinggi Departemen Pendidikan Nasional Republik Indonesia Nomor 43/DIKTI/Kep/2006 Tanggal 6 September 2006, mata kuliah Bahasa Indonesia adalah salah satu dari Kelompok Mata Kuliah Pengembangan Kepribadian (MPK) atau Mata Kuliah Dasar Umum (MKDU) di Perguruan Tinggi. Sebagai mata kuliah pengembangan kepribadian, kuliah Bahasa Indonesia lebih menitikberatkan pada pengembangan keterampilan mahasiswa dalam menggunakan bahasa Indonesia secara baik dan benar, baik lisan maupun tulis.

Keterampilan berbahasa mahasiswa tersebut dibina melalui kegiatan menyimak, berbicara, membaca, dan menulis, terutama keterampilan menulis ilmiah sesuai program studinya. Materi kuliah pada kegiatan menyimak, ditekankan pada kemampuan menyimak pembicaraan langsung, dan menyimak siaran atau tayangan melalui media. Materi berbicara, meliputi pengembangan kemampuan dalam hal keberanian bertanya, menjawab, menyanggah, mendukung suatu pendapat. Kemampuan dalam bereeminar, baik sebagai peserta, pemakalah, notulen, maupun moderator. Selain itu juga mengembangkan kemampuan dalam mempresentasikan ide atau pemikiran di depan kelas / umum. Materi membaca, meliputi pengembangan kemampuan mahasiswa dalam hal membaca kitab, buku teks, modul kuliah, hand out, koran, majalah, artikel ilmiah, dan lain-lain. Selain itu juga dikembangkan kemampuan mahasiswa dalam hal mengakses informasi melalui internet, secara cepat, cermat, tepat, efisien, dan efektif. Sedangkan materi menulis, meliputi pengembangan keterampilan mahasiswa dalam hal menulis surat, artikel polpuler, dan karya ilmiah berupa laporan praktikum, tugas akhir, skripsi, tesis dan lain-lain.

Tujuan penyelenggaraan kuliah Bahasa Indonesia pada perguruan tinggi Indonesia secara khusus agar mahasiswa, sebagai calon profesional, terampil menggunakan bahasa Indonesia yang baik dan benar, baik secara lisan maupun tertulis sebagai sarana pengungkapan gagasan ilmiah. Secara akademis diharapkan agar pada pada akhir kuliah bahasa Indonesia mahasiswa diharapkan mampu menyusun sebuah karya ilmiah sederhana dalam bentuk dan isi yang baik, dengan menggunakan bahasa Indonesia yang baik dan benar; selain itu, mahasiswa diharapkan agar mahasiswa mampu memanfaatkan keterampilannya dalam berbahasa untuk mengembangkan diri sepanjang hayat (baik melalui bahasa isyarat, lisan, maupun tulis), baik pada saat masih kuliah maupun kelak pada saat memasuki dunia kerja.

Guna mencapai tujuan tersebut, sejumlah materi dipilih dan dijadikan sebagai bahan kajian pada mata kuliah Bahasa Indonesia, meliputi pokok-pokok materi sebagai berikut: Bahasa dan Komunikasi; Bentuk dan Ragam Bahasa; Kedudukan Bahasa Indonesia; Pembinaan Kemampuan Bahasa Lisan; Pembinaan Kemampuan Bahasa Tulis; Surat Dinas; Penyusunan Laporan Karya Ilmiah; dan materi Presentasi di depan umum.

\section{METODE PENELITIAN}

Subyek penelitian adalah 34 Mahasiswa. Setting penelitian yang bersifat Action Researsc ini adalah kegiatan pengajaran mata kuliah Bahasa Indonesia pada mahasiswa semester I Tahun Ajaran 2018/2019 program studi Teknologi Industri Pertanian (TIP) Politeknik Negeri Tanah Laut. Harapan utama dari penelitian ini adalah terjadinya peningkatan hasil belajar mahasiswa pada mata kuliah Bahasa Indonesia. Untuk memenuhi harapan tersebut, maka dalam penelitian ini dilakukan pengamatan dan beberapa tindakan terhadap subyek-subyek berikut: (1) Dosen: Bagaimanakah persiapan yang dilakukan, meliputi pengorganisasian materi, memilih metode, menyiapkan sarana penunjang, serta bagaimana dosen mengelola kelas perkuliahannya. (2) Mahasiswa: Bagaimana antusiasme dan keaktifan mahasiswa dalam mengikuti perkuliahan. (3) Hasil belajar: Hasil belajar yang diperoleh pada perkuliahan Bahasa Indonesia apakah sudah sesuai dengan harapan atau belum.

Action Research ini dilaksanakan dalam dua siklus. Masing-masing siklus terdiri dari satu kali tatap muka perkuliahan, yang diawali dengan penyusunan perencanaan, dan diakhiri dengan refleksi, sehingga diperoleh sebuah kesimpulan.

Prosedur penelitian tersebut, secara skematis dapat digambarkan sebagai berikut: 


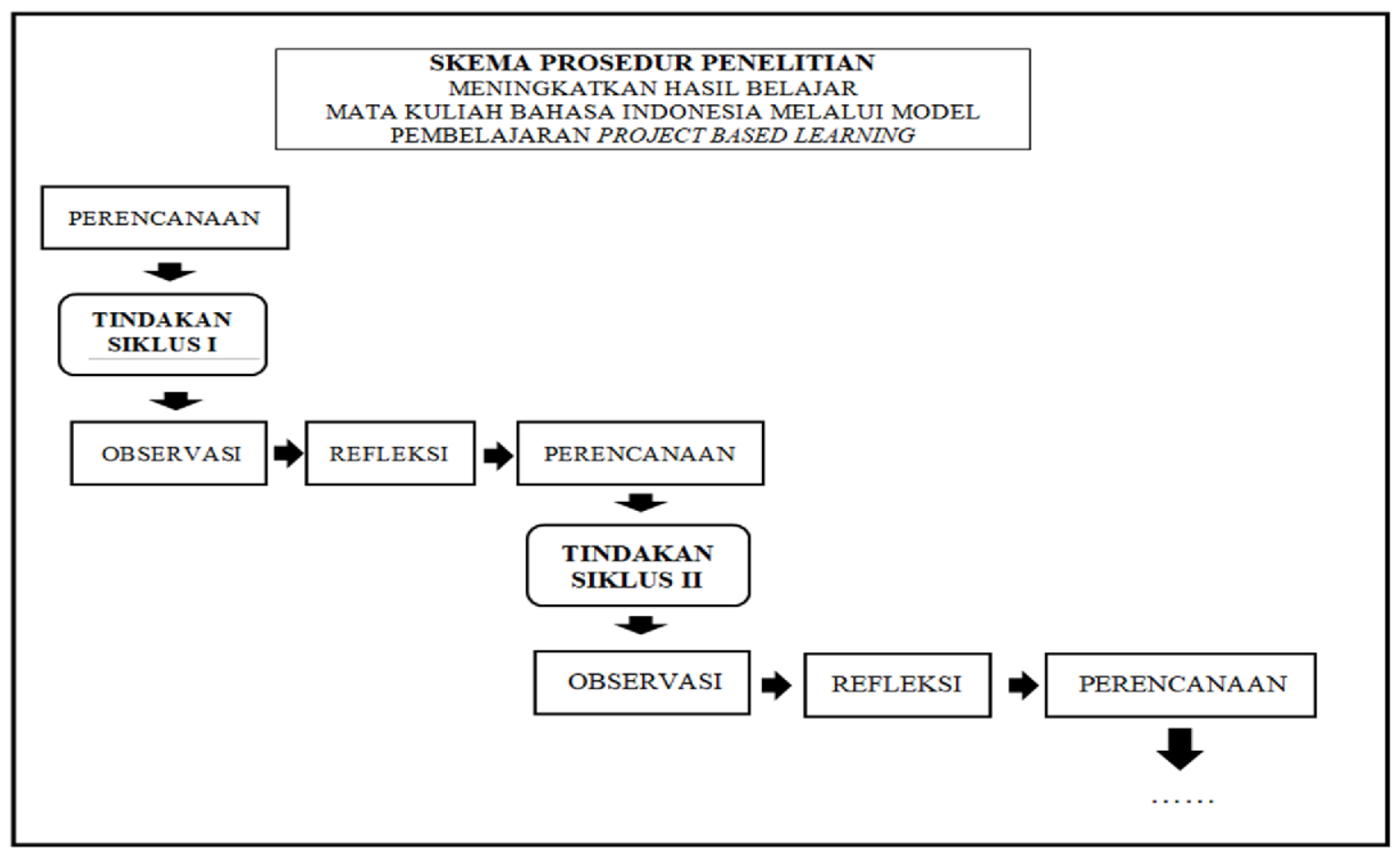

Gambar 1. Skema Prosedur Penelitian

Pada tahap perencanaan peneliti menyusun skenario pembelajaran, dalam bentuk Rencana Pembelajaran Semeseter (RPS), mendesain strategi dan scenario pembelajaran, dalam bentuk Satuan Acara Pembelajaran (SAP), mempersiapkan peralatan pendukung pembelajaran, dan merumuskan jenis dan bentuk tes hasil belajar. Seluruh kegiatan perencanaan diselesaikan sebelum pelaksanaan tindakan. Kegiatan pokok dalam tahap ini adalah pelaksanakan skenario perkuliahan tatap muka di kelas, sebagaimana yang telah disusun dalam Satuan Acara Pembelajaran (SAP), yang diakhiri dengan tes hasil belajar. Strategi perkuliahan yang dikembangkan pada siklus ini adalah konvensional sebagaimana kuliah pada umumnya, yang diisi dengan penjelasan dan paparan materi kuliah dari dosen. Kegiatan ini diiringi dengan observasi oleh pengamat. Pada akhir kuliah dilakukan tes hasil belajar.

Penelitian dilanjutkan ke siklus berikutnya. Sama halnya dengan tindakan pada siklus terdahulu, kegiatan pokok pada siklus II adalah pelaksanakan skenario perkuliahan tatap muka di kelas, sesuai dengan Satuan Acara Pembelajaran (SAP) yang telah direvisi dan disesuaikan baik alokasi waktu maupun bentuk penilaiannya. Perubahan penting yang dilakukan pada siklus II adalah mengubah strategi perkuliahan. Perkuliahan tidak lagi menggunakan strategi konvensional sebagaimana kuliah pada umumnya, yang diisi dengan penjelasan dan paparan materi kuliah dari dosen, tetapi diterapkan strategi baru yaitu dengan mengembangkan model pembelajaran Project Based Learning (PBL). Perbedaan perlakuan atau tindakan inilah yang menjadi fokus utama penelitian ini. Apakah dengan perubahan tindakan tersebut hasil belajar akan menjadi lebih baik, itulah yang akan dicari jawabnya dalam penelitian ini.

Jenis instrumen yang digunakan adalah Lembar Observasi dan Portofolio/hasil pekerjaan mahasiswa. Instrumen yang digunakan adalah: (a) Lembar Observasi, untuk memperoleh data kualitatif tentang kelancaran proses belajar mengajar yang dikembangkan dosen, keaktifan, dan partisipasi mahasiswa dalam mengikuti kuliah; (b) Tes hasil belajar mahasiswa guna memperoleh data kuantitatif tentang penguasaan kompetensi/ tingkat kelulusan atau hasil belajar mahasiswa secara akademis.

Data hasil belajar yang diperoleh dianalisis secara deskriptif kuantitatif berupa persentase un tuk melihat peningkatan yang terjadi. Data juga didukung oleh hasil observasi aktivitas mahasiswa di kelas. 


\section{HASIL DAN PEMBAHASAN}

Action Research tentang pengembangan model pembelajaran Project Based Learning (PBL) dalam rangka meningkatkan hasil belajar mahasiswa Politeknik Negeri Tanah Laut pada mata kuliah Bahasa Indonesia yang telah dilakukan memberikan gambaran hasil sebagai mana ditampikan pada tabel berikut:

Tabel 1. Data Hasil Belajar dan Aktivitas Mahasiswa

\begin{tabular}{|c|l|c|c|}
\hline \multirow{2}{*}{ No } & \multicolumn{1}{|c|}{ Aspek Yang dinilai } & \multicolumn{2}{c|}{ Persentase } \\
\cline { 3 - 4 } & & Siklus I & Siklus II \\
\hline 1 & Hasil belajar mahasiswa & $83 \%$ & $96 \%$ \\
\hline 2 & Keaktifan mahasiswa dalam mengikuti perkuliahan. & $78 \%$ & $92 \%$ \\
\hline
\end{tabular}

Dari tabel tersebut terlihat bahwa terjadi peningkatan secara signifikan dari siklus, I, dan II meskipun angka kisarannya bervariatif, namun peningkatan terjadi pada kedua aspek yang diteliti. Hasil belajar mahasiswa yang selama ini ditunjukkan dengan nilai hasil studi, masih dianggap sebagai buah terpenting darikerja perkuliahan, dari siklus I, ke II terbukti mengalami peningkatan yang sangat berarti, dari yang semula (83\%) pada siklus I, meningkat menjadi (96\%) pada siklus II setelah perkuliahan dikembangkan dengan model Project Based Learning (PBL).

Peningkatan hasil belajar ini tidak lain adalah karena adanya penerapan project based learning pada mata kuliah Bahasa Indonesia. Hal ini sesuai dengan hasil penelitian sebelumnya yang menyatakan bahwa project based learning dapat meningkatkan hasil belajar (Dewantara, 2015; Rosiyanah \& Wijayati, 2019). Hasil implementasi model PjBL membuat peserta didik lebih kreatif dan lebih mudah bagi peserta didik untuk memahami materi pembelajaran yang disampaikan oleh guru (Amalia, Abidin, \& Safitri, 2019).

Data lain yang diperoleh peneliti adalah tentang keaktifan mahasiswa. Dari siklus I, dan II nampak bahwa keaktifan mahasiswa dalam perkuliahan mengalami peningkatan yang sangat signifikan, dari persentase $(78 \%)$ dengan kriteria Sedang pada siklus I yang menggunakan metode kuliah konvensional meningkat menjadi (92\%) dengan kriteria Tinggi pada siklus II, yakni perkuliahan yang dikembangkan dengan model Project Based Learning (PBL). Hal ini sesuai dengan penelitian sebelumnya yang menyatakan bahwa project based learning dapat menstimulasi aktivitas siswa (Setiawan \& Bharati, 2019).

Project Based Learning adalah model pembelajaran yang sesuai untuk digunakan dalam proses pembelajaran yang menekankan aktivitas siswa, memberikan kebebasan untuk mengembangkan potensi mereka (Ismuwardani et al., 2019).

Model Project Based Learning akan lebih menekankan suatu pembelajaran pada berpusat pada siswa di mana siswa sebagai subjek kegiatan belajar lebih mandiri dalam menyelesaikan pekerjaan otentik sebagai hasil dari pembelajaran (Amalia et al., 2019). Project Based Learning memberikan kesempatan belajar berbasis inquiry yaitu pengalaman terstruktur sehingga setiap mahasiswa melaksanakan penyelidikan seputar masalah yang terjadi (Niswara et al., 2019). Project Based Learning juga meningkatkan kepercayaan diri siswa. Project Based Learning memberikan motivasi kepada siswa untuk mengeksplorasi kemampuan mereka. Ini membuka ruang bagi siswa untuk menunjukkan keberadaan mereka di kelas (Jaya et al., 2019).

\section{KESIMPULAN}

Kesimpulan dari penelitian ini adalah bahwa Model Project Based Learning (PBL) mampu meningkatkan hasil belajar mahasiswa semester I Tahun Ajaran 2018/2019 untuk mata kuliah Bahasa Indonesia pada program studi Teknologi Industri Pertanian (TIP) Politeknik Negeri Tanah Laut Kalimantan Selatan. Hal ini karena project based learning membantu mahasiswa mengkonstruksi pngetahuannya dan meningkatkan keaktivan mahasiswa dalm perkuliahan.

Berdasarkan hasil penelitian ini disarankan agar pembaca dapat mencoba menggunakan model project based learning dalam pembelajaran untuk meningkatkan hasil belajar mahasiswa. Selain itu, penelitian lebih lanjut mengenai penerapan model project based learning pada berbagai topik sangat diperlukan. 


\section{DAFTAR PUSTAKA}

Amalia, P. I., Abidin, S. F. F., \& Safitri, S. R. (2019). Project-based Learning in Chinese Classroom: A Way to Stimulate Students. KnE Social Sciences, 3(10), 77. https://doi.org/10.18502/kss.v3i10.3890

Dewantara, D. (2015). Pengaruh Brainstorming dalam Project Based Learning terhadap Kemampuan Analisis dan Berpikir Kreatif Pada Materi Impuls-momentum. DISERTASI Dan TESIS Program Pascasarjana UM.

Irmawati, A., Khoirunnisya, \& Syarifah, E. (2019). Pembelajaran menulis cerita fantasi menggunakan model project based learning. Parole (Jurnal Pendidikan Bahasa Dan Sastra Indonesia, 2(1), 109-114.

Ismuwardani, Z., Nuryatin, A., \& Doyin, M. (2019). Implementation of Project Based Learning Model to Increased Creativity and Self-Reliance of Students on Poetry Writing Skills. Journal of Primary Education, 8(40), 51-58.

Jaya, A., Hermansyah, \& Rosmiyati, E. (2019). The implementation of project-based learning in increasing speaking achievement and self-confidence. Indonesian Educational Administration and Leadership Journal (IDEAL), 1(1), 4-14.

Lao, H. (2019). Meningkatkan Hasil Belajar Mata Pelajaran Animasi 3 Dimensi Peserta Didik Kelas XII MM SMK Negeri 5 Pekanbaru Dengan Model Pembelajaran Project Based Learning Dan Metode Pembelajaran Demonstrasi. Jurnal Pendidikan Tambusai, 3(1), 483-491.

Niswara, R., Muhajir, M., \& Untari, M. F. A. (2019). Pengaruh model project based learning terhadap high order thinking skill. Mimbar PGSD Undiksha, 7(2), 85-90.

Rosiyanah, S., \& Wijayati, N. (2019). Students Critical Thinking Skills in Project-Based Learning Assisted by Edmodo Social Networking Site. Journal of Innovative Science Education, 8(40), 544-551.

Setiawan, A., \& Bharati, D. A. L. (2019). The Preliminary Research of Developing HOT ProjectBased-Speaking Assessment to Stimulate the Students' Critical Thinking and Creativity. UNNES International Conference on English Language Teaching, Literature, and Translation (ELTLT 2018) The, 188, 346-349. https://doi.org/10.2991/eltlt-18.2019.66

Suantara, K. D., Darmawiguna, I. G. M., \& Sugihartini, N. (2019). Pengembangan E-Modul Berbasis Model Pembelajaran Project Based Learning pada Mata Pelajaran Pemrograman Desktop Kelas XI Rekayasa Perangkat Lunak di SMK Negeri 2 Tabanan. Karmapati, 8(2), 1-10. Retrieved from https://ejournal.undiksha.ac.id/index.php/KP/article/view/9386/6015

Teguh, Suyanto, E., \& Munaris. (2019). Pengembangan Bahan Ajar Menulis Puisi Berbasis Project Based Learning Siswa Kelas X. J-Simbol (Bahasa, Sastra, Dan Pembelajarannya), (April), 1-8. 